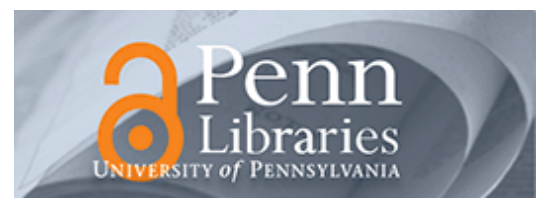

Manuscript Studies

Volume 3

Issue 2 Fall 2018

Article 3

2019

\title{
Provenance in the Aggregate: The Social Life of an Unremarkable Arabic Manuscript Collection
}

Paul Love

Al Akhawayn University, p.love@aui.ma

Follow this and additional works at: https://repository.upenn.edu/mss_sims

Part of the Arabic Studies Commons, and the Medieval Studies Commons

\section{Recommended Citation}

Love, Paul (2019) "Provenance in the Aggregate: The Social Life of an Unremarkable Arabic Manuscript Collection," Manuscript Studies: Vol. 3 : Iss. 2 , Article 3.

Available at: https://repository.upenn.edu/mss_sims/vol3/iss2/3

This paper is posted at ScholarlyCommons. https://repository.upenn.edu/mss_sims/vol3/iss $2 / 3$

For more information, please contact repository@pobox.upenn.edu. 


\title{
Provenance in the Aggregate: The Social Life of an Unremarkable Arabic Manuscript Collection
}

\author{
Abstract \\ This is a biography of a collection of eleven Arabic manuscripts at the library of the Università degli Studi \\ di Napoli L'Orientale (UNO). These manuscripts do not contain otherwise unknown or even rare texts, \\ since the titles in the collection exist in dozens of manuscript copies in northern African libraries in \\ addition to printed editions. While the bulk of their content may be known to historians, the objects \\ themselves have led rich social lives that merit attention. Like many biographies, however, the story of \\ these objects suffers from a lack of detail. In this article, I suggest that if approached in the aggregate, \\ the long-term provenance of Arabic manuscript collections like this one have a fascinating story to tell \\ about their social histories. Even in the absence of every detail, these objects have much to say about the \\ multiple and overlapping historical contexts through which they have moved. \\ I begin by showing how these manuscripts at the UNO started their lives as Italian papers, situating them \\ in the world of maritime and terrestrial trade that linked the northern and southern coasts of the \\ Mediterranean from the 17th-20th centuries. I then demonstrate how the production and circulation of \\ these texts speaks to widespread intellectual networks of a Muslim minority community and its \\ manuscript culture in the Maghrib during the 18th and 19th centuries when the Ottoman empire \\ attempted to exercise influence over the region. Finally, I show the ways in which these manuscripts were \\ participants in the process of European (specifically, Italian) colonization and colonial knowledge \\ production in northern Africa at the end of the 19th and beginning of the 20th centuries. By placing the \\ aggregated biographies of the manuscripts in dialogue with the history of the broader Mediterranean \\ world, I show how Arabic manuscript collections like this one have much to offer historians.
}

\section{Keywords}

Arabic manuscripts, Provenance, Libya, Italy, Naples, Ottoman, Ibadi, Colonial Knowledge Production, Paper History, Watermarks, Manuscript studies, libraries, social history, Università degli Studi di Napoli L'Orientale (UNO), collecting history 


\section{MANUSCRIPT STUdiES}

A Journal of the Schoenberg Institute for Manuscript Studies

VOLUME 3, NUMBER 2

(Fall 2018)

Manuscript Studies (ISSN 2381-5329) is published semiannually

by the University of Pennsylvania Press

The Schoenberg Institute
for Manuscript Studies
University of Pennsylvania Libraries 


\title{
MANUSCRIPT STUDIES
}

\author{
VOLUME 3, N UMBER 2 \\ (Fall 2018)
}

\section{ISSN 2381-5329}

Copyright ( 2018 University of Pennsylvania Libraries and University of Pennsylvania Press. All rights reserved.

Published by the University of Pennsylvania Press, 3905 Spruce Street, Philadelphia, PA 19104.

Printed in the U.S.A. on acid-free paper.

Manuscript Studies brings together scholarship from around the world and across disciplines related to the study of premodern manuscript books and documents, with a special emphasis on the role of digital technologies in advancing manuscript research. Articles for submission should be prepared according to the Chicago Manual of Style, $16^{\text {th }}$ edition, and follow the style guidelines found at http://mss.pennpress.org.

None of the contents of this journal may be reproduced without prior written consent of the University of Pennsylvania Press. Authorization to photocopy is granted by the University of Pennsylvania Press for libraries or other users registered with Copyright Clearance Center (CCC) Transaction Reporting Service, provided that all required fees are verified with CCC and paid directly to CCC, 222 Rosewood Drive, Danvers, MA 01923. This consent does not extend to other kinds of copying for general distribution, for advertising or promotional purposes, for creating new collective works, for database retrieval, or for resale.

\section{SUBSCRIPTION INFORMATION:}

Single issues: $\$ 30$

Print and online subscriptions: Individuals: \$40; Institutions: \$92; Full-time Students: \$30 International subscribers, please add $\$ 18$ per year for shipping.

Online-only subscriptions: Individuals: $\$ 32$; Institutions: $\$ 80$

Please direct all subscription orders, inquiries, requests for single issues, address changes, and other business communications to Penn Press Journals, 3905 Spruce Street, Philadelphia, PA 19104. Phone: 215-573-1295. Fax: 215-746-3636. Email: journals@pobox.upenn.edu. Prepayment is required. Orders may be charged to MasterCard, Visa, and American Express credit cards. Checks and money orders should be made payable to "University of Pennsylvania Press" and sent to the address printed directly above.

One-year subscriptions are valid January 1 through December 31. Subscriptions received after October 31 in any year become effective the following January 1 . Subscribers joining midyear receive immediately copies of all issues of Manuscript Studies already in print for that year.

Postmaster: send address changes to Penn Press Journals, 3905 Spruce Street, Philadelphia, PA 19104.

Visit Manuscript Studies on the web at mss.pennpress.org. 


\section{MANUSCRIPT STUDIES}

A Journal of the Schoenberg Institute for Manuscript Studies

VOLUME 3 , NUMBER 2

\section{Articles}

Notes of Exchange: Scribal Practices and Vernacular

Religious Scholarship in Early Modern North India

Tyler Williams

Translating Machiavelli's Prince in Early Modern England:

New Manuscript Evidence

Alessandra Petrina

Provenance in the Aggregate: The Social Life of an Arabic

Manuscript Collection in Naples

Paul Love

Illuminated Leaves from an Ethiopic Gospel Book in the

Newark Museum and in the Walters Art Museum

JACOPO GNISCI

Re-Conceptualizing the Poems of the Pearl-Gawain

Manuscript in Line and Color

Maidie Hilmo

\section{Annotations}

A Codicological Assessment of Three Gospel Books with

Sideways-Oriented Illustrations Displayed in the

Metropolitan Museum of Art's Armenia Exhibition

ZsUZsANNA GULÁCSI

A Psalter from Maillezais at Maynooth

Peter J. Lucas and Angela M. Lucas 
iv | Journal for Manuscript Studies

A Dossier of Texts for the Augustinian Hermits of Lucca

Thomas M. Izbicki

Digitizing the University of Pennsylvania's Indic Manuscripts

Benjamin J. Fleming

Reviews

Kathryn M. Rudy. Piety in Pieces: How Medieval Readers

Customized Their Manuscripts

A. R. BennetT

Georgi R. Parpulov. Toward a History of Byzantine Psalters, ca. 850-1350 AD

Barbara Crostini

Corine Schleif and Volker Schier, eds. Manuscripts

Changing Hands

JoHAN OOSTERMAN

495

Nichols, Stephen G. From Parchment to Cyberspace:

Medieval Literature in the Digital Age

BRIDGET WHEARTY

499

List of Manuscripts Cited

505 


\title{
Provenance in the Aggregate \\ The Social Life of an Arabic Manuscript \\ Collection in Naples
}

\author{
PaUl Love \\ Al Akhawayn University in Ifrane- \\ School of Humanities
}

His is a biography of a collection of eleven Arabic manuscripts at
the library of the Università degli Studi di Napoli L'Orientale
(UNO). ${ }^{1}$ These manuscripts do not contain otherwise unknown or
even rare texts, since the titles in the collection exist in dozens of manu-

Funding for this research was provided by the Council of American Overseas Research Centers, the Social Sciences Research Council, the Woodrow Wilson Foundation, and the University of Michigan International Institute. Many thanks to Derek Elliott and Phillip Naylor for comments on earlier iterations of the paper. Additional sincere thanks to the anonymous reviewers from JMS, whose criticisms and suggestions helped refine and improve the argument. Special thanks also to Antonella Muratgia of the Special Collections Library of the Università degli Studi di Napoli L'Orientale for her help in locating the manuscripts described here and to Stefano Bigliardi for help revising the translations from Italian. Any errors, shortcomings, or limitations are my own.

1 On the non-Ibadi Arabic manuscripts of the UNO, see Giuseppe Celentano and Cielia Sarnelli Cerqua, "I Manoscritti di Medicina Araba dell'Istituto Universitario Orientale di Napoli," in Studi in onore di Francesco Gabrieli nel suo ottantesimo compleanno, vol. 1 (Rome: Università di Roma La Sapienza, 1984), 210-36; Cielia Sarnelli Cerqua, "Le fonds de manuscrits arabes de l'institut universitaire oriental de Naples," Revue d'bistoire Maghrébine, 1992, 147-50. 
script copies in northern African libraries in addition to printed editions. While the bulk of their content may be known to historians, the objects themselves have led rich social lives that merit attention. Like many biographies, however, the story of these objects suffers from a lack of detail. In this article, I suggest that if approached in the aggregate, the long-term provenance of Arabic manuscript collections like this one has a fascinating story to tell about their social histories. Even in the absence of every detail, these objects have much to say about the multiple and overlapping historical contexts through which they have moved. ${ }^{2}$ The data drawn from the manuscripts themselves comes from a 2017 catalog. ${ }^{3}$

I begin by showing how these manuscripts at the UNO started their lives as Italian papers, situating them in the world of maritime and terrestrial trade that linked the northern and southern coasts of the Mediterranean from the seventeenth through the twentieth centuries. I then demonstrate how the production and circulation of these texts speaks to widespread intellectual networks of a Muslim minority community and its manuscript culture in the Maghrib during the eighteenth and nineteenth centuries when the Ottoman Empire attempted to exercise influence over the region. Finally, I show the ways in which these manuscripts were participants in the process of European (specifically, Italian) colonization and colonial knowledge production in northern Africa at the end of the nineteenth and beginning of the twentieth centuries. By placing the aggregated biographies of the manuscripts in dialogue with the history of the broader Mediterranean world, I show how Arabic manuscript collections like this one have much to offer historians.

2 In referring to the "social lives" or the "biographies" of these objects, I draw inspiration from the studies in Arjun Appadurai, The Social Life of Things: Commodities in Cultural Perspective (Cambridge: Cambridge University Press, 1988).

3 The catalog includes codicological descriptions, including notes on and images of watermarks. It is available at https://www.academia.edu/34506748/Catalog_of_Ibadi_ Manuscripts_at_the_Universita_degli_Studi_di_Napoli_LOrientale_in_Naples (accessed 18 March 2018). 


\section{Provenance Versus Content}

Among the many "oriental" manuscripts at the UNO, there is a collection of eleven Arabic manuscripts, most of which are stored in a brown metal shelving unit in the Special Collections office. To many historians, these manuscripts are unremarkable since most of their contents have long existed in printed editions. This privileging of edited, scholarly editions of texts along with the accompanying lack of interest in provenance or the material history of the objects themselves has often meant a lost opportunity for historians to explore the social life of Arabic manuscripts. Recent years have seen a growing number of valuable studies that shed light on the social uses of Islamic manuscripts in Arabic script and the performance of the texts in their late-medieval contexts. ${ }^{4}$ Plotting those early chapters from the lives of manuscripts and their uses on an aggregated timeline of provenance stretching from the production of their paper to their arrival in modern libraries demonstrates the interconnected character of content, use, and historical context.

The later chapters in the lives of Arabic manuscripts have received far less attention than earlier stages. The provenance of Arabic manuscript holdings in European or North American libraries usually takes second place to their contents. Formation of such collections has not traditionally interested the historians who use them, with their provenance normally meriting only an introductory paragraph or a footnote. ${ }^{5}$ This was the case

4 For example, see the collection of studies in Andreas Görke and Konrad Hirschler, eds., Manuscript Notes as Documentary Sources (Beirut: Orient-Institut, 2012). For other recent examples, see Konrad Hirschler, The Written Word in the Medieval Arabic Lands: A Social and Cultural History of Reading Practices (Edinburgh: Edinburgh University Press, 2012); Joel Blecher, Said the Prophet of God: Hadith Commentary Across a Millennium (Oakland: University of California Press, 2017).

5 This is in strong contrast with interest in provenance among librarians of Arabic and Islamic manuscript collections or codicologists. Recent examples include Dagmar A. Riedel, "Manuscripts, Printed Books, and Near Eastern Studies in North America: The Manuscripts in Arabic Script of the Columbia University Libraries," Journal of Islamic Manuscripts 6, no. 2-3 (2015): 280-310; Catherine Ansorge, "Cambridge University Library Islamic Manuscript Collection: Origins and Content," Journal of Islamic Manuscripts 7, no. 2 (2016): 127-51; Herre de Vries, "Reading the Book's History: Understanding the Repairs and Rebindings on 
for a collection of Arabic manuscripts in Naples in 1948, when Italian Orientalist Roberto Rubinacci published descriptions of them, prefaced by the following paragraph:

In 1913, Professor Francesco Beguinot, while reorganizing documents held in the archives of the bureau of a [Ottoman] Turkish mutasarrif [prefect] of Yefren in Tripolitania [in northwestern Libya], found a group of Ibadi [Muslim] manuscripts and lithographs piled up in an unorderly heap. Unfortunately, humidity and mice had already begun their destructive work. In the same year, the Italian journalist and special envoy of the Corriere della Sera Giuliano Bonacci found additional Ibadi manuscripts in the same area of the Jebel Nefusa. The manuscripts and lithographs were sent to the Ministero delle Colonie, which at the request of Professor Beguinot were subsequently directed to the Biblioteca dell'Istituto Universitario Orientale di Napoli, where they are still preserved. ${ }^{6}$

These were the notes Rubinacci provided on the provenance of this collection of manuscripts and a handful of lithograph books from Tripolitania in Libya. While the lithographs eventually made their way into the library's stacks, the manuscripts went into the Special Collections of what is today the UNO.

Rubinacci's matter-of-fact summary of the journey of these books from the bureau of an Ottoman official in the town of Yefren and unnamed locations in the mountainous regions of northwestern Libya to a library in Naples belies a much richer biography. Encapsulated in this brief note are

Islamic Manuscripts in the Vatican Library and Their Implications for Conservation," Journal of Islamic Manuscripts 7, no. 3 (2016): 339-83. An interesting exception among historians has been the history of Arabic manuscript collections in Spain: Nabil Matar, "Arabic Books and a Moroccan Treasure: Colonel Percival Kirke and Mulay Ismail, 1682-1683,” Seventeenth Century 26 (2011): 119-29; Daniel Hershenzon, “Traveling Libraries: The Arabic Manuscripts of Muley Zidan and the Escorial Library," Journal of Early Modern History 18, no. 6 (2014): 535-58.

6 Roberto Rubinacci, "Notizia di alcuni manoscritti ibāḍiti esistenti presso l'Istituto Universitario Orientale di Napoli," Annali dell'Istituto Universitario Orientale di Napoli 3 (1949): 431. 
hints of how these manuscripts reflect the world of early modern Mediterranean trade as well as to a manuscript tradition among an Ibadi Muslim minority in northern Africa. Neither Sunni nor Shi'i Muslims, Ibadi communities have been in northern Africa since at least the mid-eighth century, where their scattered settlements have made up an archipelago of towns and villages stretching from the Algerian Sahara, through southern Tunisia, and into the mountains of northwestern Libya. ${ }^{7}$

Finally, Rubinacci's note on the provenance of the manuscripts reflects a more recent history of imperial reform, war, resistance, and colonial knowledge production. These details of the social life of these manuscripts are at once typical of the provenance of northern African manuscripts in European libraries and unique to the history of Libya.

\section{From Italy to Africa}

Although they became manuscripts in northern Africa, the Naples manuscripts began their lives as papers produced in Europe. Unlike southern Iberia or western Asia, central and eastern northern Africa were never home to grand centers of paper production. Instead, the eastern half of the "Maghrib" (the "western region" in Arabic) relied on paper imports or, until a relatively late date, the use of parchment as a writing surface. ${ }^{8}$ By the end of the thirteenth century, dominance in the Mediterranean over the production and export of paper began moving northward to the Italian peninsula, where several important innovations to paper production including copper molds and watermarks had drastically improved the quality and renown of Italian

7 For overviews of the history and doctrines of the Ibadis, see Pierre Cuperly, Introduction à l'étude de l'ibāạisme et de sa théologie (Alger: Office des publications universitaires, 1984); John Wilkinson, Ibādism: Origins and Early Development in Oman (Oxford: Oxford University Press, 2010); Adam Gaiser, Muslims, Scholars, Soldiers: The Origins and Elaboration of the Ibāẹ̄ Imamate Traditions (Oxford: Oxford University Press, 2010); Valerie J. Hoffman, The Essentials of Ibād̄ İlam (Syracuse, NY: Syracuse University Press, 2012).

8 Jonathan Bloom, Paper Before Print: The History and Impact of Paper in the Islamic World (New Haven: Yale University Press, 2001), 85. 
papers. ${ }^{9}$ One of the closest markets for these papers was just across the water in the neighboring regions of Träblus (Tripolitania or modern northwestern Libya) and Ifríqiy $\bar{a}$ (roughly modern Tunisia). ${ }^{10}$ Italian merchant ships regularly stopped in the port cities both here and along the rest of the northern African littoral from the thirteenth century onward, where they sold goods, including paper. ${ }^{11}$

Scholarly communities in the Maghrib and Egypt made up an eager market for European paper. Arabic- and Berber-speaking scholars of northern Africa lived in a vibrant manuscript culture from the Middle Period (eleventh through sixteenth centuries) all the way up to the twentieth century. From the seventeenth century onward, there was an especially strong "thirst for knowledge" in the form of books that spread from the western fringes of the Sahara all the way to Egypt. ${ }^{12}$ Moreover, a dense network of

9 On the development of paper technologies in Italy, see Richard L. Hills, "Early Italian Papermaking: A Crucial Technical Revolution," in Produzione e Commercio Della Carta e Del Libro Secc. XIII-XVIII, ed. Simonetta Cavaciocchi (Florence: Le Monnier, 1992), 73-97; Theo Laurentius and Frans Laurentius, Italian Watermarks, 1750-1860 (Leiden: Brill, 2016), 1-6.

10 These northern Italian papers were produced exclusively for African and western Asian markets; see Natalia Viola, "A propos des papier filigranés dans les manuscrits arabes provenant de l'Afrique de l'Ouest," Journal of Islamic Manuscripts 6 (2015): 357. Papermakers elsewhere in the Italian peninsula, especially in famous sites of production like the Amalfi coast, provided paper to regional archives in the eighteenth and nineteenth centuries, evidenced by the watermarks cataloged from archival documents in Laurentius and Laurentius, Italian Watermarks, $1750-1860$.

11 For example, on the relationship between Venetian merchants and the Hafsids of Tunisia, see Bernard Doumerc, Venise et l'émirat hafside de Tunis (1231-1535): Bernard Doumerc (Paris: L'Harmattan, 1999). For further references to both earlier and later trade agreements between Italian city-states and northern Africa, see Paul Love, "Writing a Network, Constructing a Tradition: The Ibadi Prosopographical Corpus in Medieval Northern Africa (11th-sixteenth C.)” (Ph.D. dissertation, University of Michigan, 2016), 193-96.

12 The phrase belongs to Ghislaine Lydon: "A Thirst for Knowledge: Arabic Literacy, Writing Paper, and Saharan Bibliophiles in Southwestern Sahara," in Graziano Krätli and Ghislaine Lydon, The Trans-Sabaran Book Trade Manuscript Culture: Arabic Literacy and Intellectual History in Muslim Africa (Leiden: Brill, 2011), 35-72. On books in northwestern Africa and the Sahara, see both the other chapters in that same volume and Ghislaine Lydon, On TransSabaran Trails: Islamic Law, Trade Networks, and Cross-Cultural Exchange in NineteenthCentury Western Africa (Cambridge: Cambridge University Press, 2009); Houari Touati, “Écriture et commerce dans le Sahara précolonial," Studia Islamica 107 (2012): 122-31. 
scholars and traders connected the constellations of cities, towns, and villages across northern Africa and created a common market for Arabic books.

Alongside traveler accounts and a few scattered trading statistics from the eighteenth and nineteenth centuries, additional evidence for this market of Italian and other European papers comes from watermarks. Merchants transported European watermarked paper to port cities along the African littoral like Bougie, Algiers, Tunis, Tripoli, and Alexandria. From there, the papers were transported along the various caravan routes linking the coast to the interior of the Sahara and Sahel regions. ${ }^{13}$

The Naples manuscripts belonged to this larger world of Mediterranean and Saharan trade in the eighteenth and nineteenth centuries. The watermarks of these manuscripts echo the dominance of Italian papers in the markets of coastal Tunisia and Tripolitania. The ubiquitous "Tre Lune" watermark, first associated with northern Italian papermaker Valentino Galvani and popular throughout northern Italy, appears multiple times throughout the collection in manuscripts transcribed in the late eighteenth century. ${ }^{14}$ Marks associated with Galvani's grandson, Andrea (such as the "Three Moon Faces" mark), alongside the popular mark known as the "Tre Cappelli" ("three hats") also appear in a manuscript dating to the eighteenth century, as do the early to late nineteenth-century companion "Three moon faces" and "BNeC" watermarks associated with Italian papermaker Bernardino Nadori. ${ }^{15}$ Central Maghribi Muslim communities shared a preference

13 The relevant travel accounts and related sources have been compiled in Terence Walz, "The Paper Trade of Egypt and the Sudan in the Eighteenth and Nineteenth Centuries and Its Re-Export to the Bilād as-Sūdān," in Krätli and Lydon, Trans-Sabaran Book Trade, 73-107. 14 “Tre Lune” examples include Naples MS ARA 30 (fols. 159 and 160); MS ARA 50 (fols. 21 and 22); MS ARA 71 (fols. 5 and 6). For a catalog of this mark in Ottoman manuscripts, see Asparuch Velkov, Les filigranes dans les documents ottomans: trois croissants (Sofia: Éd. "Texte-Trayanov," 1983). On the history and ubiquity of this mark, see also Viola, "A propos des papier," esp. 353.

15 “Tre Cappelli" in Naples MS ARA 50 (fols. 120 and 126); the "BNeC" mark appears in Naples MS ARA 93 (e.g., fols. 2 and 9, although the "e" was not visible in all the examples I identified). On BNeC marks, see Walz, “The Paper Trade of Egypt and the Sudan,” 87. 
for (especially northern) Italian paper with their coreligionists across northern and western Africa. ${ }^{16}$

Assuming the Naples manuscripts were transcribed in the Tripolitania region or somewhere nearby, their paper supports likely made their way to the mountains of the interior via either the island of Jerba (in southern Tunisia) or the city of Tripoli. Merchants would have either sold those Italian papers in the coastal markets or transported them to the interior via caravans, to be sold either to booksellers or directly to consumers. Until the late nineteenth century, caravans transported goods, including paper, from Tripoli all the way to the Fezzan in the Libyan Sahara before moving westward across the desert. ${ }^{17}$ One of the many eager markets for manuscripts was the community of Ibadi Muslim scholars in the mountains of western Tripolitania.

Like their coreligionists elsewhere in the region, Ibadis in the eighteenth and nineteenth centuries purchased these Italian papers that were sold in port cities or transported by caravans. ${ }^{18}$ The Jebel Nafusa region was home to some of the oldest and best-known Ibadi scholarly names in Africa. ${ }^{19}$ The paratexts of the manuscripts suggest that it was in the villages of the Jebel

16 On paper and manuscripts in west Africa, see Jonathan Bloom, "Paper in Sudanic Africa," and Sheila Blair, "Arabic Calligraphy in West Africa," both in Shamil Jeppie and Souleymane Bachir Diagne, eds., The Meanings of Timbuktu (Cape Town: HSRC Press, 2008), 45-76. On the appearance of the same northern Italian watermarks in manuscripts from west Africa and the Sahel from similar periods, see Viola, "A propos des papier."

17 On paper moving along trade routes out of and through Tripolitania, see Paul Masson, Histoire des établissements et du commerce français dans l'Afrique barbaresque (1560-1793) (Algérie, Tunisie, Tripolitaine, Maroc) (Paris: Hachette, 1903), 177-78; 320; Henri Auguste Omant, ed., Missions archéologiques françaises en Orient aux XVIIe et XVIIIe siècles. Documents publiés par H. Omont. (Imprimerie Nationale, 1902), 1048; Jakob Gräberg di Hemsö, "Prospetto del commercio di Tripoli d'Affrica e della sue relazioni con quello dell' Italia. Articolo 1," in Antologia, vol. 27 (Florence: Gabinetto scientifico e letterario di G.P. Vieusseux, 1827), 90.

18 On the ubiquity of Italian watermarks in Ibadi manuscripts, see, e.g., Paul M. Love, "Ibādī Manuscripts in the Bibliothèque Nationale de Tunisie: Descriptions, Watermarks, and Implications," Journal of Islamic Manuscripts 7 (2016): 1-35.

19 On the history of the region, see Mazhūdī Mas' ūd, Jabal Nafūsa: mundhu intishār al-islām ḅattā hijrat Bañ̄ Hilāl ilā bilād al-maghrib ([Online edition]: Tawalt, 2003). 
Nafusa and on the nearby island of Jerba that these Italian papers were used by Ibadi scholars to produce their manuscripts.

\section{Early Modern Ibadi Manuscript Culture}

Ibadi Muslim communities in northern Africa produced large numbers of manuscript books, especially from the sixteenth century onward. ${ }^{20} \mathrm{~A}$ handful of places made up the centers of early modern Ibadi manuscript production: the towns of the Mzab valley in the Algerian Sahara, the island of Jerba in Tunisia, and the villages of the Jebel Nafusa in Libya. A varied corpus of legal, theological, and prosopographical texts circulated among these different centers, including texts composed during the earliest centuries of Islam as well as original works and commentaries on classical texts into the twentieth century. The colophons of those manuscripts in Naples that include the names of their copyists reflect the continuing importance of these places as centers for the production of manuscripts in the eighteenth and nineteenth centuries. Arabic names normally end with a reference to a toponym associated with their family (referred to as a nisba, or attributive adjective). The Naples manuscripts include Ibadi copyists with the names "al-Nafūsī," referring to someone from the Jebel Nafusa, and "al-Mașabī", in reference to someone from the Mzab valley. ${ }^{21}$

Ibadi manuscript culture was informal, with few of the highly stylized characteristics of its Egyptian or Syrian contemporaries in both the medieval and early modern periods like statements of audition ( $\operatorname{sam} \bar{a}(\bar{a} t)$ or reading certificates $(i j \bar{a} z \bar{a} t)$. Nevertheless, the output was impressive, and the extant manuscripts are held today in hundreds of private Ibadi libraries in

20 Much of this section is an abbreviated form of "Paper and People" in Love, "Writing a Network," 193-229.

21 "[Written] in the hand of its copyist, for his own use and for whomsoever God desires after him, Sulaymān b. Mūsā b. 'Aysā . . . al-Nafūsı”” (Naples MS ARA 30, fol. 188.b); "[Writ-

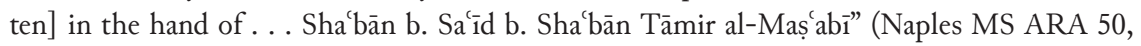
fol. 157.a). 
the Maghrib. ${ }^{22}$ From the early seventeenth century onward, Cairo also became a center of manuscript production when Maghribi Ibadis founded a trade agency and school known as the "Buffalo Agency" (Wikālat al-Jāmūs), where students and scholars copied and studied manuscripts for the next few centuries. ${ }^{23}$

The Naples manuscript collection reflects this manuscript culture in terms of period and content. It comprises eighteenth- and nineteenthcentury copies of historical, juridical, and prosopographical works composed during the period of the thirteenth through the sixteenth centuries when the Ibadi tradition began to crystallize. These include three important juridical texts by Abū Sākin 'Umar al-Shammākhī (d. 1279), two copies of an early history of Islam by Abū l-Qāsim al-Barrādī (d. early fifteenth century) entitled the Book of Choice Pearls (Kitāb al-jawābir al-munțaqāt), and the most comprehensive Ibadi prosopography, the Book of Traditions (Kitāb al-siyar) by Abū 1-Abbās al-Shammākhī (d. 1522). ${ }^{24}$ Likewise, the collection includes commentaries (sharb) by one of the most famous Ibadi authors of commentaries, Muhammad b. 'Umar al-Qaṣbī al-Sidwīkshī (d. 1677), a scholar from Jerba who spent many years at the Buffalo Agency in Cairo. Al-Sidwīkshī's nickname, "the glossator" (al-muḅashshī), hints at the large number of commentaries he wrote during his many years living

22 Recent surveys of manuscript collections have suggested that there are over 125 private libraries in the Mzab valley in Algeria. Dozens of these collections have now been fully cataloged as part of an ongoing effort by Ibadi cultural organizations in the Mzab, including,

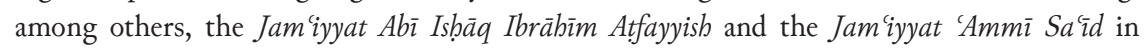
Ghardaia. For example, ten different catalogs of collections were published electronically as a CD-ROM as "al-Fahāris al-'āshir lil-makhțūțāt" (CD-ROM, Windows), Arabic (Ghardaia: Mu'assasat al-shaykh 'Ammī Sa īd, 2010). Inventoried libraries on the island of Jerba include the al-Bārūnī family library, the manuscript collection belonging to the family of Sālim b. Yáqūb (d. 1991), and the al-Bāsī mosque library.

23 Aḥmad Muṣlaḥ, al-Waqf al-jarbì fì Miṣr wa-dawrubu fì 'l-tanmiya al-iqtisāadiyya wa-'lijtimā'iyya wa-'l-thaqāfiyya min al-qarn al-'āshir ilā 'l-qarn al-rābic 'ashar al-bijrīyayn (Wikālat al-Jāmūs namūdhajan) (Kuwait: al-Amāna al-'Āmma lil-Awqāf, 2012). On manuscript culture at the Buffalo Agency, see especially pages $127-80$.

24 Naples MS ARA 71 (composite manuscript); Naples MS ARA 93 (Kitāb al-jawābir-the second copy does not have a shelfmark); Naples MS ARA 30 (Kitāb al-siyar). 
there. ${ }^{25}$ His family, several generations of which traveled to Cairo from Jerba to study, represents one of many connections between the Ibadi community in Egypt and the rest of northern Africa, especially the island of Jerba. ${ }^{26}$

Alongside content, the ownership statements found in several volumes also reflect aspects of early modern Ibadi manuscript culture. Parts of the collection appear to have moved together through a few different owners from the late eighteenth through the early twentieth centuries. Ownership statements range from the names of the owners written on multiple folios to more formal ownership paratexts. For example, the first folio of Naples MS ARA 50 contains references to three of the manuscript's previous owners. The oldest, located in the center of the first folio, following the title, reads:

This is ... the composition of the scholar Shaykh Yahyā al-Janāwanī (may God have mercy on him).... [Its] generous owner is our Shaykh Ahmad al-Ba'țūr. May God favor the health of them all, Amen. ${ }^{27}$

In addition to ownership history, examples like this also give details of the Ibadi manuscript production process as well as collecting practices. The copyist notes that the manuscript does not belong to him, indicating that the owner commissioned the copy to be made. In other cases, colophons note that copyists made the manuscripts for their own use (typically employing the phrase "for himself" (li-nafsibi).$^{28}$ In the example above, the part of

25 The title given for this manuscript in Rubinacci's description was "Commento di Muḥammad Abū Sittah al-Qaṣbī alle Qāwāe id di Abū Țāhir Ismā̄êl b. Mūsà al-Ǧayțālī” (Rubinacci, "Notizia," 431).

26 Muhammad Șāliḥ Nāṣir Bābāâmmī, ed., Mu'jam a lām al-ibādiyya (Dictionnaire des hommes illustres de l'Ibadisme, les hommes du Maghreb), vol. 2 (Beirut: Dār al-Gharb al-Islāmī, 2000), 389-90.

27 "hādhā al-kitāb . . . ta'līf al-'allāma al-shaykh Yahyā al-Janāwan̄i rahimahu Allāh . . . wa-'l-mālik al-mubārak shaykhunā Aḥmad al-Ba'țūr ạ̣sana Allāh 'āfiyat al-jamīe amīn” (MS ARA 50, fol. 1.a).

28 E.g., Naples MS ARA 30 (fol. 1.88.b). Cf. "Ownership Statements” in Adam Gacek, Arabic Manuscripts: A Vademecum for Readers (Leiden: Brill, 2009), 173-77. 
this statement attributing its original ownership was crossed out when its new owner acquired it. In the top left corner of the same folio, there is a second short statement that has also been crossed out but begins "Property of 'Iyād b. Qìrāt." These two statements are accompanied by a third mark of ownership, the name "Sha'bān Būmiswar" written three times in pencil on each side of the original ownership statement and once in purple ink over the second.

The two families mentioned in six of the manuscripts are Bin Qīrāt and Bümiswar. Interestingly, these two families, along with the third family mentioned in the example above, al-Ba'țūr, are associated historically not only with Jebel Nafusa but also with the nearby island of Jerba. ${ }^{29}$ The ownership statements with associated dates include one belonging to Ahmad al-Ba'tūur (1761-62) and several associated with various members of the Bin Qìrāt family (1818-19, 1819-20, 1824-25, 1841-42)..$^{30}$ The core of the collection thus appears to have belonged to a member of the Bin Qīrāt family in the early to mid-eighteenth century.

The later ownership statements in these manuscripts bearing the name Būmiswar are all associated with the same individual: Sha'bān Būmiswar. ${ }^{31}$ This Shåbān purchased the Bin Qīrāt manuscripts, evidenced by his name appearing alongside each Bin Qīrāt ownership statement. This could be the same Shàbān Būmiswar who lived at the beginning of the twentieth century and was later responsible for the "Būmiswar Zāwiya," otherwise known

29 The Ba tụur family library is said to have been lost to an arson attack sometime after 1987. An inventory of the collection was published in that year in a small booklet entitled $Q \bar{a}$ 'imat al-kutub al-mawjūda fī 'l-maktabāt al-kbāsșa wa-'l-'āmma (Hūmat al-sūq: Jam'iyyat șiyānat jazīrat Jarba, 1987). The name "Aḥmad al-Ba'țūr" appears in the ownership statement of Naples MS ARA 50, fol. 1.a. Branches of the Bin Qirāt family also still live in Jerba today (locally pronounced "Bin Gīrāṭ").

30 Members of the Bin Qirrāt family are mentioned in ownership statements in MS ARA 50 (fol. 1.a); MS ARA 259 (fol. 1.a); a copy of the Kitāb al-jawāhir by Abū al-Qāsim al-Barrādī (no shelfmark, fol. 75.b); two additional manuscripts that I did not examine but that were mentioned in Rubinacci, "Notizia," 432, 438.

31 The name Sha'bān Būmiswar appears in ownership statements in Naples MS ARA 50 (fol. 1.a); Naples MS ARA 259 (fol. 1.a); MS ARA [no shelfmark, "Kitāb al-jawābir"] (fol. 75.b); as well as in two additional manuscripts described in Rubinacci, "Notizia," 432, 438. 
as the "Great Mosque" on the island of Jerba. ${ }^{32}$ This Ibadi mosque in Jerba was in a district (shaykbat) run by members of the Bümiswar family in the first half of the twentieth century, although it is today associated with the better-known al-Bārūnī (Barouni) family. The library of the Great Mosque, also called the "Miswariyya" library, is often assumed to have been absorbed into the al-Bārūnī library, which is today the largest manuscript library on the island of Jerba. ${ }^{33}$ Both the Būmiswar and al-Bārūnī families originated in Libya, and members of the families continue to live there, demonstrating the close historical ties between Jerba and the nearby Jebel Nafusa, where some of the Naples manuscripts traveled next.

A final note regarding Ibadi manuscript culture in the nineteenth and twentieth centuries deserves mention. In the introduction to his catalog of Ibadi manuscripts in Naples quoted above, Rubinacci noted that several lithographs had been sent with the manuscripts to the UNO at the same time. In the late nineteenth century, Ibadi publishing houses in Cairo printed and distributed key Ibadi texts in lithograph form to bookstores and dealers throughout the Maghrib. ${ }^{34}$ Although widely distributed, printed editions of Ibadi texts did not suddenly supplant manuscript copies of them. On the contrary, as was the case for other communities in Cairo, Ibadi manuscript culture existed alongside and complemented a growing print culture in the late nineteenth and early twentieth centuries. ${ }^{35}$ It is not surprising, then, to find that a book collection found in the Jebel Nafusa included both printed books and manuscripts. Unfortunately, unlike the manuscripts,

32 A Sha'bān Būmiswar also appears in French colonial-era documents as the man responsible for the mosque. See Archives Nationales de Tunisie FPC / D / 0088 /0008 / (0001-0004) (1916-1958).

33 A team of researchers from the Association Abū 1-Ishāq Ibrāhīm Ațfayyish in Ghardaia, Algeria, is currently (mid-2018) finishing a comprehensive catalog and history of the Barouni family library. Their study will deal with this history in detail. In the interim, see Paul M. Love, "Écouter le conte d'un manuscrit: penser avec une copie d'une chronique ibadite de la bibliothèque Barouni à Djerba," Études et Documents Berbères 35-36 (2016): 301-13.

34 Martin H. Custers, Ibā d̄ $\bar{\imath}$ Publishing Activities in the East and in the West, c. 1880-1960s: An Attempt to an Inventory, with References to Related Recent Publications (Maastricht: n.p., 2006).

35 Kathryn A. Schwartz, "The Political Economy of Private Printing in Cairo as Told from a Commissioning Deal Turned Sour, 1871," International Journal of Middle East Studies 49, no. 1 (2017): esp. 27-29. 
the titles and authors of the lithographs brought to the UNO were not specifically identified by Rubinacci, so little more can be said about their relationship to the manuscript texts.

The ownership statements and other paratexts also situate the production, use, and movement of the UNO Ibadi manuscripts in important moments of Libyan and, more broadly, northern African history. The midnineteenth century saw the reassertion of the Ottoman Empire's authority in Libya (or, more precisely, the regions of Tripolitania and Cyrenaica) after a period of quasi-independence under the Qaramanli dynasty (1711-1835). ${ }^{36}$ Watermarks, dates of transcription, and ownership statements ranging from the mid-eighteenth to the mid-nineteenth centuries situate the Naples manuscripts in the Qaramanli period and later. ${ }^{37}$ Ibadi scholars were transcribing these manuscripts in a period of both great intellectual activity for their community and great change in the region. In the second half of the nineteenth century, the Ottoman Empire gradually reasserted its control over Tripolitania but by the beginning of the twentieth century had lost what little symbolic control it held over its other northern African territories to the ever-growing influence of European colonial powers. The Naples manuscripts would witness and document those changes.

\section{Ottomans, Manuscripts, and Colonialism in the Maghrib}

The primary actors in the next chapter in the life of the Naples manuscripts were soldiers, officials, and academics connected to the French and nascent Italian colonial empires. The North African colony of Algeria and the neighboring protectorate of Tunisia were the products of nineteenth-century French colonialism (established in 1830 and 1881, respectively). Likewise,

36 Mostafa Minawi, The Ottoman Scramble for Africa: Empire and Diplomacy in the Sabara and the Hijaz (Stanford, CA: Stanford University Press, 2016).

37 Naples MS ARA 30, dated August 1773 (fol. 188.b); MS ARA 50, dated 1762 (fol. 157.b); MS ARA 71, dated after 1791-92 (fol. 16.a, fol. 27.b); MS ARA 259, ownership statement dated 1824-25 (fol. 1.a); Kitāb al-jawābir (no shelfmark), dated 1774 (fol. 75.a); Kitāb qawāìi al-islām, dated 1819 (see Rubinacci, "Notizia," 432.) 
British and French interference in Egypt and the Sudan had been ongoing since the French invasion of Alexandria in 1798.

By contrast, Italian colonialism in Libya only began following the end of the Italo-Turkish (i.e., Ottoman) war with the signing of the Treaty of Lausanne in 1912, in which the Ottoman Empire ceded political control of part of its wilayat (province) to the Italians. The following year, the Italian army moved into Tripolitania and took control of the remainder of the country in March 1913. ${ }^{38}$

Throughout northern Africa in the nineteenth and early twentieth centuries, thousands of manuscripts were confiscated from private libraries as well as from collections in zawiyas, mosques, and other public institutions by French colonial authorities, in particular. ${ }^{39}$ Manuscripts were also purchased or confiscated by other European travelers, researchers, and soldiers as objects of study or as souvenirs. ${ }^{40}$ In some cases, such as the well-known Arabic manuscript collection at the library of the University of Algiers, those manuscripts remained in country in a new centralized location run by the French colonial government. ${ }^{41}$ Following independence, the national libraries and archives of other countries in the Maghrib like Tunisia and Morocco also attempted to collect manuscript collections large and small into their newly created national libraries. ${ }^{42}$

The relatively late experience of colonialism in Libya meant that Arabic manuscripts had previously remained in the hands of private individuals or

38 Dirk J. Vandewalle, A History of Modern Libya (Cambridge: Cambridge University Press, 2012), 24-30.

39 Arab Abdelhamid, Manuscrits \& bibliothèques musulmanes en Algérie (Méloans-Revel: Atelier Perrousseaux, 2006).

40 For examples of Ibadi manuscripts, in particular, see, e.g., Abderrahmane Ayoub, "Deux pièces d'archive retrouvée parmi les documents de feau Jean Auguste Bossoutrot," Revue d'bistoire Maghrébine 21-22 (1981): 93-94; Pieter Sjoerd van Koningsveld, "The Arabic Manuscripts Collection of René Basset (1855-1924),” Biblothec Orientalis 30 (1973): 370-85.

41 Abdi Abdallah, "Histoire de la Bibliothèque Universitaire d'Alger et de sa reconstitution après l'incendie du 7 juin 1962,” Université d'Alger Bibliothèque Universitaire website, n.d., http://bu.univ-alger.dz/Reconstitution_de_la_B.U.pdf.

42 Jocelyn Hendrickson, "A Guide to Arabic Manuscript Libraries in Morocco, with Notes on Tunisia, Algeria, Egypt, and Spain," MELA Notes: Journal of Middle Eastern Librarianship 81 (2008): 15-88. 
mosques while that region was under Ottoman control. Manuscripts in the mountainous region of western Tripolitania, in particular, remained in private Ibadi collections. ${ }^{43}$ This was in large part due to the context and experience of Italian colonization of Libya, where colonialism differed markedly in both chronology and character from other northern African countries.

Italians were not brand new to Tripolitania in the twentieth century. As noted above, commercial relations between the shores of the Mediterranean also had a much longer history since Italian and Libyan merchants had been trading in, among other things, paper for centuries. More recently, there had also been an Italian presence in the region in the form of trade agencies and Italian-language schools that had been in operation since the Ottoman period of the late nineteenth century. Tripoli was a cosmopolitan center in large part thanks to rigorous Ottoman reforms that brought remarkable changes in education, administration, and the military during the tanzimat era of the second half of the nineteenth century. ${ }^{44}$ In the field of education in Tripolitania, new military academies taught pupils English, and private schools offered instruction in Italian to (mostly Jewish) inhabitants of Tripoli. ${ }^{45}$ Other marks of change came with the introduction of a telegraph connecting Malta and Tripoli and a printing press that issued the first Arabic and Turkish newspaper, Western Tripoli (Trābulus al-gharb). ${ }^{46}$

Administrative reforms in the late Ottoman era also carried over into the early colonial period. The official reorganization of Tripoli as a province (wilayat) during the Ottoman era meant that "there were four permanent sanjaqs (local districts), each administered by a mutasarrif," or prefect. ${ }^{47}$

43 Amr Khalifa Ennami, "A Description of New Ibadi Manuscripts from North Africa," Journal of Semitic Studies 15, no. 1 (1970): 63-87; F. M. Shambesh, ed., "Libya," in World Survey of Islamic Manuscripts, vol. 4 (London: Al-Furqān Islamic Heritage Foundation, 1994), 265-78.

44 Lisa Anderson, "Nineteenth-Century Reform in Ottoman Libya," International Journal of Middle East Studies 16, no. 3 (1984): 325-48.

45 Federico Cresti, "La formation pour les musulmans de Libye à l'époque coloniale, ou les supposés dangers de la modernité," Revue des mondes musulmans et de la Méditerranée, no. 101-2 (2003): 269-304.

46 Anderson, "Nineteenth-Century Reform in Ottoman Libya," 330.

47 Anderson, "Nineteenth-Century Reform in Ottoman Libya," 330. 
Important to the history of the Naples manuscripts, the prefect of the Jabal al-Gharb district was centered in the Ibadi city of Yefren, where the manuscripts originated. In the early years of the colonial era, the Italians would intentionally not dismantle this administration set up by the Ottomans, and some local elites and administrators took advantage of the colonial presence to solidify their authority. ${ }^{48}$ The choice to leave the existing Ottoman administration in place during the early colonial period stemmed from the Italians' relative lack of experience in colonial administration and unfamiliarity with the local religious and social contexts.

Formally established in the same year as the Italians claimed sovereignty over much of Libya, the French protectorate of Morocco was to be a carefully planned colonial enterprise drawing on nearly a century of experience in Algeria and decades in Tunisia. ${ }^{49}$ By contrast, the Italians had no similar experience on which to model their colonial administration. Prior to the war, for example, Italian academics had virtually no knowledge of local religious groups in Libya. ${ }^{50}$ Over the course of the nineteenth century, the French had constructed an "empire of facts" comprising ethnographic, geological, historical, and religious studies of the peoples who lived in Algeria. ${ }^{51}$ Italians had no comparable body of scholarship from which to draw in Libya, and Arabic manuscripts and lithograph books would play important roles in the production of knowledge about Islam in Libya.

As had been the case for the French in Algeria, it took many years for Italian forces to consolidate power over their new territory after the invasion

48 Ali Abdullatif Ahmida, Forgotten Voices: Power and Agency in Colonial and Postcolonial Libya (New York: Routledge, 2005), 21-24; Anna Baldinetti, "Italian Colonial Rule and Muslim Elites in Libya: A Relationship of Antagonism and Collaboration,” in Guardians of Faith in Modern Times "ulama" in the Middle East, ed. Meir Hatina (Leiden: Brill, 2009), 91-108.

49 Susan Gilson Miller, A History of Modern Morocco (Cambridge: Cambridge University Press, 2013), 88-161; Edmund Burke, The Ethnographic State: France and the Invention of Moroccan Islam (Berkeley: University of California Press, 2014); Jonathan Wyrtzen, Making Morocco, Colonial Intervention and the Politics of Identity (Ithaca, NY: Cornell University Press, 2015).

50 Baldinetti, "Italian Colonial Rule."

51 George R. Trumbull IV, An Empire of Facts: Colonial Power, Cultural Knowledge, and Islam in Algeria, 1870-1914 (Cambridge: Cambridge University Press, 2009). 
in 1911-12. It was only much later, in the 1930s, that "Libia" gained its official status in Italy and became the object of a concerted effort of agricultural reform and settler colonialism. ${ }^{52}$ In the earliest days following the end of the Italo-Turkic war, plans were made (although only put into practice much later) for the creation of government-run Islamic schools to educate a new generation of Muslim scholars in Arabic and Italian. The implementation and success of these institutions waxed and waned-mostly waning, as they failed to produce scholars of the desired caliber and influence. ${ }^{53}$ Moreover, two different poles of religio-political authority were constantly competing with the Italian attempts to consolidate control. One was the famous Sanusi Sufi brotherhood that had been expanding and solidifying its power from Cyrenaica to the Lake Chad region. ${ }^{54}$ The second was the residual authority of the Ottomans concentrated in Tripolitania to the west.

One way in which Ottoman influence persisted was in the realm of law. In the years following the end of the Italo-Turkish war, the Italian colonial government attempted to recognize as valid preexisting Ottoman laws and local customs. ${ }^{55}$ From the very beginning, however, these attempts to adapt to circumstances on the ground were misinformed and ultimately undermined the colonial project. Anna Baldinetti has noted that the Italians had a "poor knowledge of Islamic jurisprudence and of the religious situation in Tripolitania and Cyrenaica." ${ }^{56}$ This contributed to the subversion of their own claims to authority in the Treaty of Lausanne, which

not only allowed the [Ottoman] sultan to continue to be mentioned as caliph in Friday prayer. It also permitted the chief qadi [i.e., judge], whose task it was to protect the inhabitants' religious interests, to

52 Vandewalle, A History of Modern Libya, 30-40.

53 Cresti, "La formation pour les musulmans de Libye."

54 Vandewalle, A History of Modern Libya, 26-29; Lisa Anderson, The State and Social Transformation in Tunisia and Libya, 1830-1980 (Princeton, NJ: Princeton University Press, 1986), 114-40.

55 Claudia Gazzini, "When Jurisprudence Becomes Law: How Italian Colonial Judges in Libya Turned Islamic Law and Customary Practice into Binding Legal Precedent," Journal of the Economic and Social History of the Orient 55, no. 4-5 (2012): 746-70.

56 Baldinetti, "Italian Colonial Rule," 92. 
be appointed directly by the şeybülislâm in Istanbul—this is, in the name of the sultan. These provisions made the Italian occupation look illegal and embodied an admission of the chief qadi as a sort of vice-sultan, who would act as a protector of the native believers against Italian abuses. ${ }^{57}$

Alongside the terms of the Treaty of Lausanne, another form of continuing Ottoman influence in the region proved a thorn in the side of the Italians in the years following colonization: the opposition to the Italians among the Ibadi tribes of the Jebel Nefusa. After the invasion of Tripoli, Ibadis in the Jebel Nefusa region west of the city were led in organized opposition by Sulaymān al-Bārūnī (d. 1940). ${ }^{58}$ A member of the elite Ottoman-era "notable class" ('ayān), ${ }^{59}$ al-Barūnī had been a representative in the Ottoman government following the Young Turks revolution (1908), and after the invasion he took on the role of rebel-leader in the fight against the Italians. Following the defeat of the tribes in Tripolitania, al-Bārūnī went into exile, where he had a long and varied career, including as a diplomat in Oman. ${ }^{60} \mathrm{Al}-\mathrm{B} a \bar{r} u \bar{n} \overline{1}$ was not only a politician, he and several of his comrades were also scholarsand scholars own books. It is here that opposition to the Italian invasion in Libya, colonial knowledge production, and the provenance of a collection of Arabic manuscripts in Naples intersect.

57 Baldinetti, "Italian Colonial Rule," 92.

58 Angelo Del Boca, Mobamed Fekini and the Fight to Free Libya., trans. Antony Shugaar (New York: Palgrave Macmillan, 2011), 38-39.

59 Ali abdullatif Ahmida, The Making of Modern Libya: State Formation, Colonization, and Resistance, 1830-1932 (New York: State University of New York Press, 1994), 65.

60 Vandewalle, A History of Modern Libya, 26; Amal N. Ghazal, "An Ottoman Pasha and the End of Empire: Sulayman al-Baruni and the Networks of Islamic Reform," in Global Muslims in the Age of Steam and Print (Berkeley: University of California Press, 2014), 40-58. Another possible connection is found in the colophon carried by one of the manuscripts of the Kitāb al-jawāhir (no shelfmark), which says it was copied for Abū Yáqūb Yūsuf b. 'Umar b. 'Alī al-Bārūnī (fol. 75.b), presumably of the same al-Bārūnī family. To my knowledge, however, this individual is otherwise unknown. 


\section{The Bureau of an Ottoman Prefect}

As Rubinacci noted in the introduction to his 1949 catalog, several of the manuscripts and lithographs in the collection in Naples were taken from the office of the Ottoman prefect in the village of Yefren. Although Rubinacci did not mention the name of this official, it happens that the prefect of Yefren was a relatively well-known figure: a man named Mūsā Bey "Grāda." A close colleague of Sulaymān al-Bārūnī, Mūsā Grāda held the title of mutasarrif in addition to being the acting mayor ( $r a^{3} \bar{\imath}$ s al-baladiyya) of the town of Yefren.${ }^{61}$ Following the Italian invasion of Tripolitania, Grāda went into exile with al-Bārūnī to Tunis. ${ }^{62}$ If Rubinacci's account is accurate, it was in the (by-then empty) office of Grādā that several of the Ibadi manuscripts and lithographs were found and subsequently taken, boxed up, and sent to southern Italy.

Which of the books and manuscripts came originally from Mūsā Grāda's archive and which were found elsewhere by the Corriere della Sera reporter Giuliano Bonacci is not clear. Bonacci spent 1912-13 as a correspondent during the Italian invasion. ${ }^{63}$ It was presumably while following the Italian army as it moved into the Jebel Nefusa region in 1913 that he found these manuscripts. The precise circumstances of their journey from the Jebel Nafusa to Naples and the reason for Bonacci's having taken them in the first place remain unknown.

The choice of the Istituto Universitario Orientale di Napoli as a destination for the Mūsā Grāda lithographs and manuscripts and those acquired by Bonacci was obvious, however. This institution had been founded in the eighteenth century and had long specialized in the study of Eastern cultures

61 Del Boca, Mohamed Fekini and the Fight to Free Libya, 43; Baldinetti, "Italian Colonial Rule," 97.

62 Anna Baldinetti, "Libya's Refugees, Their Places of Exile, and the Shaping of Their National Idea," in Nation, Society, and Culture in North Africa (London: Frank Cass, 2003), 73. 63 The online archive of the Corriere della Sera lists dozens of articles by Bonacci, many of which describe the situation on the ground in Libya, including Tripolitania and the Tunisian frontier in 1912. See http://archivio.corriere.it/ (accessed 1 May 2017). 
and religions, especially Sinology. ${ }^{64}$ The university was also home to professor Francois Beguinot, head of the Oriental Institute and the man named by Rubinacci as responsible for choosing where to send the manuscripts after their transfer to the newly established (1912) Ministry of Colonies. As someone who through his own academic writing "attempt[ed] to find a scholarly justification for Italy's colonization of [Libya], Beguinot exemplifies the link between historical scholarship and colonial knowledge production. ${ }^{65}$ However, Beguinot and Rubinacci were not the only scholars to link Ibadi and Berber studies to the Italian colonial project in northern Africa. Ibadi manuscripts and lithograph texts were part of a much broader change in Italian Orientalist studies that developed directly out of the colonial experience. Valeria Fiorani Piacentini has recently written that "it is possible to say that the colonial experience brought Ibādism [to] the core of Islamic studies in Italy, and had a strong impact on some remarkable personalities. All of them were high-ranking officials and later became eminent scholars, like Carlo Alfonso Nallino, Umerto Hizzitano, Roberto Rubinacci, Amedeo Guillet, Enrico Cerulli, Mario Martino Moreno, and several other ones."66

Through its scholars and its organ-the Annali dell'Istituto Universitario Orientale - the University of Naples l'Orientale produced research on Ibadi Muslim communities both during the colonial period (1912-43) and continuing afterwards. Orientalist scholars at the UNO during the colonial era benefited from the Italian government's interest in Islam in Libya and desire to understand both its past and present. Especially after 1911, "Ibādisism became one of the central issues of inquiry, in particular North-African Ibādism, no longer a theoretical issue of debate [but] rather . . . a positive reality." ${ }^{67}$ These Ibadi manuscripts at the UNO were part of the political reality of Italian colonial efforts in northern Africa. It was in Naples that

64 Valeria Fiorani Piacentini, “The Italian Perspective and Contribution to Ibāḍī Studies,” in Today's Pespectives on Ibadi History, ed. Reinhard Eisener, Studies on Ibadism and Oman (Hildesheim: Georg Olms Verlag, 2017), 35-48.

65 Brian L. McLaren, Architecture and Tourism in Italian Colonial Libya: An Ambivalent Modernism (Seattle: University of Washington Press, 2006), 118.

66 Piacentini, "The Italian Perspective," 40 (emphasis mine).

67 Piacentini, “The Italian Perspective," 40. 
the Ibadi manuscripts from the library of the Ottoman prefect of Yefren received the attention of Italian Orientalists like Laura Veccia Vaglieri and Roberto Rubinacci even after Italy's withdrawal from its "fourth shore" by the end of World War II. ${ }^{68}$

\section{Conclusion}

In combining these details in the aggregate by adopting a long-term understanding of provenance and broad historical context, I have attempted to show how a collection of Arabic manuscripts like the Ibadi texts at the UNO have led complex social lives. The purpose in presenting the story has been to think about the provenance of a collection of Arabic manuscripts on the level of collection and in a duration that is much longer than the past century, the last owner, or even the copyist. Approaching the Naples Ibadi manuscripts from this perspective allows for a holistic appreciation of provenance that begins with the production of the paper and extends all the way to the present. This approach offers historians an opportunity to explore both the history and politics of manuscript collections. In addition, it shows that even in the absence of all the details, in the aggregate, collections like the Ibadi manuscripts in Naples have much to say about the multiple historical contexts through which they have moved.

68 Ersilia Francesca, "Ibāḍ̄i Studies in Naples: Rereading the Works of Last Century Italian Scholars," in Ibadi Theology: Rereading Sources and Scholarly Works, Studies on Ibadism and Oman 4 (Hildesheim: Georg Olms Verlag, 2015), 13-22. 


\section{Appendix: Inventory of Ibadi Manuscripts at the Università degli Studi di Napoli L'Orientale ${ }^{69}$}

Thanks to the guidance of the UNO Special Collections Librarian, Antonella Muratgia, I had access to the collection during a visit in November 2014. Three of the manuscripts described by Rubinacci were unaccounted for, while two additional manuscripts not mentioned by him were stored with the others, and one additional manuscript, which we could not find, appears in the university's electronic catalog.

1. MS ARA [no shelfmark], "Fiqh Ibadite" (noted on the paper sleeve in which the fragment is stored)

2. MS ARA 259, Kitāb mukbtașar al-kbisāal (The Brief Compendium of Legal Characteristics) by Abū Isḥāq Ibrāhīm ibn Qays (not dated)

3. MS ARA 30, Kitāb al-wad' al-mukbtasar fì 'l-fiqh (The Brief Compendium of Jurisprudence) by Abū Zakarīyā Yáqūub b. al-Khayr al-Jannāwanī (dated $1762 \mathrm{CE}$ )

4. MS ARA 71, [Composite manuscript containing:] Kitäb al-shafa' (The Book of Preemption); Kitāb al-biba (The Book of Donation); Kitāb al-wașāya (The Book of Bequests) by Abū Sākin 'Āmir b. 'Alī al-Shammākhī (not dated)

5. MS ARA 30, Kitāb al-siyar (The Book of Traditions) by Abū al-'Abbās Aḥmad al-Shammākhī (dated Jumāda al-awwal, 1773 CE)

6. MS ARA 93, Kitāb al-jawābir al-muntaqāt (The Book of Choice Pearls) by Abū al-Qāsim al-Barrādī (not dated)

7. MS ARA (no shelfmark), Kitāb al-jawābir al-muntaqāt by Abū al-Qāsim al-Barrādī [second copy] (dated $1774 \mathrm{CE}$ )

8. [Not found] Kitäb qawā id al-Islām (The Book of the Regulations of Islam) by Abū Țāhir Ismā̄̄îl al-Jayțālīio

9. [Not found] Qanātir al-kbayrāt (The Bridges of Blessings) by the Abū Tāhir Ismā̄il al-Jayțầlī ${ }^{71}$

10. [Not found] A mukhtașar (abridgement) by Muhammad b. Mulūka al-Tūnisī of alDurra al-bayd̄à' (The White Pearl) of 'Abd al-Raḥmān al-Akhḍarī (dated $1841 \mathrm{CE})^{72}$

11. MS ARA 51 [Unknown title] $]^{73}$

69 The following shelf marks correspond either to slips of paper stored with the manuscripts in the Special Collections library or to the current online university catalog at http://opacol. unior.it/SebinaOpac/Opac (accessed 1 May 2017).

70 Rubinacci, “Notizia," 431-32.

71 Rubinacci, “Notizia,” 437-38.

72 Rubinacci, "Notizia," 438. The author of the abridged work, 'Abd al-Rahmān b. Muhammad al-Akhḍarī (d. 1575), was a Maliki rather than an Ibadi Muslim.

73 This manuscript appears in the university's electronic catalog, and the description identifies it as part of a collection of Ibadi manuscripts donated by Francesco Beguinot in 1913. Based on the number of folios and measurements in that description, it does not appear to be any of the remaining three manuscripts in Rubinacci's article. 


\section{List OF MANUSCRIPTS CITED}

Baltimore, Walters Art Museum

W.527: 374 n. 33

W.530.A: 374 n. 33

W. $531: 374$ n. 33

W.838: 358, 360, 362, 362 fig. 5, 364

table 1, 365-77, 380-2

W.839: 358, 360, 361 fig. 4, 362, 365-77, 370 n. $29,380-2$

W.840: 358, 360, 360 fig. 3, 365-77, 370

n. $29,380-2$

Boru Śəllase Monastery

Gospels of Boru Śllase: 367, 367 n. 17, 369-72, 373 fig. 7, 374-82, 376 fig. 8, 378 fig. 9

Cambridge, MA, Harvard University, Houghton Library MS Eng. 1014: 306, 316-17, 317 n. 38, 320, 330

MS Richardson 28: 441 n. 12, 442 n. 14

Chandigarh, Punjab University, AC Joshi

Library

MS 1428: 292 n. 39

MS M-105: 292 n. 39

Cleveland, Cleveland Museum of Art 1942.1511: 374 n. 33

Däbrä Hayq Hsțifanos Monastery

Gospels of Iyäsus Mo'a: 377-78, 377 n. 40, 379 fig. 10, 381

Däbrä Täamina Monastery

Gospels of Däbrä Tä’amina: 367, 367 n. 18, 369-72, 372 fig. 6, 374-75, 381-82
Dublin, Trinity College Library

MS 58: 366 n. 10

Edinburgh, National Library of Scotland MS Hawthornden 2064: 306, 318, $318 \mathrm{n}$. 41, 320-21, 330-31

Florence, Biblioteca Medicea Laurenziana Plut. 1.56: 374 n. 33, 422

The Hague, National Library of the

Netherlands

MMW 10 A 19: 412, 412 n. 57

Jaipur, Maharaja Sawai Singh II Museum MS 2440.28: 288, 288 n. 33

Jaipur, Rajasthan Oriental Research Institute MS 2165: 296

Jodhpur, Rajasthan Oriental Research

Institute

MS 24778: 294 n. 42

MS 26094: 286-87

MS 26334: 277 fig. 3

MS 26579: 296; 297 fig. 6

MS 27518: 284 fig. 4

Leiden, Rijksuniversiteitbibliothek

BPL 108: 435

BPL 111: 435

Scaliger 38: 435

London, British Library

MS 2 B I: 398, 399 fig. 10, 407, 410

MS Add. 5111: 374 n. 33

MS Add. 62925: 403-4, 405 fig. 13

MS Cotton Nero A.x: 383-90, 383 n. 1, 384 n. 3, 388 fig. 1, 389 fig. 2, 390 fig. 3, 
391 fig. 4, 391 fig. 5, 392 fig. 6, 392-407, 394 fig. 7, 395 fig. 8, 401 fig. 11, $406 \mathrm{f}$ ig. 14,408 n. 48, 408 n. 49, 409-20, 411 fig. 15

MS Egerton 1070: 401 n. 32

MS Harley 364: 306, 317, 317 n. 39, 320

MS Harley 966: 305

MS Harley 967: 302, 306

MS Harley 2292: 306

MS Harley 5903: 311 n. 30

MS Harley 5906b: 311 n. 30

MS Harley 5908: 311 n. 30

MS Harley 5909: 311 n. 30

MS Harley 5910: 311 n. 30

MS Harley 5914: 311 n. 30

MS Harley 5915: 311 n. 30

MS Harley 5916: 311 n. 30

MS Harley 5917: 311 n. 30

MS Harley 5918: 311 n. 30

MS Harley 5919: 311 n. 30

MS Harley 5920: 311 n. 30

MS Harley 5921: 311 n. 30

MS Harley 5922: 311 n. 30

MS Harley 5923: 311 n. 30

MS Harley 5924: 311 n. 30

MS Harley 5925: 311 n. 30

MS Harley 5926: 311 n. 30

MS Harley 5927: 311 n. 30

MS Harley 5928: 311 n. 30

MS Harley 5929: 311 n. 30

MS Harley 5930: 311 n. 30

MS Harley 5931: 311 n. 30

MS Harley 5932: 311 n. 30

MS Harley 5933: 311 n. 30

MS Harley 5934: 311 n. 30

MS Harley 5935: 311 n. 30

MS Harley 5936: 311 n. 30

MS Harley 5937: 311 n. 30

MS Harley 5938: 311 n. 30

MS Harley 5939: 311 n. 30

MS Harley 5940: 311 n. 30

MS Harley 5941: 311 n. 30

MS Harley 5942: 311 n. 30
MS Harley 5943: 311 n. 30

MS Harley 5944: 311 n. 30

MS Harley 5945: 311 n. 30

MS Harley 5946: 311 n. 30

MS Harley 5947: 311 n. 30

MS Harley 5948: 311 n. 30

MS Harley 5949: 311 n. 30

MS Harley 5950: 311 n. 30

MS Harley 5951: 311 n. 30

MS Harley 5952: 311 n. 30

MS Harley 5953: 311 n. 30

MS Harley 5954: 311 n. 30

MS Harley 5956: 311 n. 30

MS Harley 5957: 311 n. 30

MS Harley 5958: 311 n. 30

MS Harley 5959: 311 n. 30

MS Harley 5960: 311 n. 30

MS Harley 5961: 311 n. 30

MS Harley 5962: 311 n. 30

MS Harley 5963: 311 n. 30

MS Harley 5964: 311 n. 30

MS Harley 5965: 311 n. 30

MS Harley 5966: 311 n. 30

MS Harley 5967: 311 n. 30

MS Harley 5968: 311 n. 30

MS Harley 5969: 311 n. 30

MS Harley 5970: 311 n. 30

MS Harley 5971: 311 n. 30

MS Harley 5972: 311 n. 30

MS Harley 5973: 311 n. 30

MS Harley 5974: 311 n. 30

MS Harley 5975: 311 n. 30

MS Harley 5976: 311 n. 30

MS Harley 5977: 311 n. 30

MS Harley 5978: 311 n. 30

MS Harley 5986: 311 n. 30

MS Harley 5987: 311 n. 30

MS Harley 5988: 311 n. 30

MS Harley 5989: 311 n. 30

MS Harley 5990: 311 n. 30

MS Harley 5991: 311 n. 30

MS Harley 5992: 311 n. 30

MS Harley 5993: 311 n. 30 
MS Harley 5994: 311 n. 30

MS Harley 5995: 311 n. 30

MS Harley 5996: 311 n. 30

MS Harley 5997: 311 n. 30

MS Harley 5998: 311 n. 30

MS Harley 6795: 306

MS Royal 6 E VI: 396, 396 n. 21

MS Royal 6 E VII: 396, 396 n. 21

MS Royal 16 G VI: 403, 403 n. 40, 404

fig. 12

MS Royal 19 B XV: 393 n. 19

MS Sloane 885: 311 n. 30, 312

MS Sloane 1044: 311 n. 30

MS Sloane 1086: 311 n. 30

MS Sloane 1983: 311 n. 30

London, Lambeth Palace Library

MS Arc.L.40.2/E.23: 307

MS Arc.L.40.2/E.25: 307

MS Arc.L.40.2/E.64: 308 n. 22

MS Sion L40.2/E24: 307-8, 309 fig. 1, 312-15, 316 fig. 2, 318-19, 321-29, 325

fig. 3, 328 fig. 4, 331-33, 331 n. 50, 332 fig. 5

London, University College London

Library

MS Ogden 7: 305 n. 13

Los Angeles, J. Paul Getty Museum

MS 33: 413-14, 413 fig. 16

MS 89: 370-71, 370 n. 31

Manchester, John Rylands Library

Hindustani MS 1: 275 fig. 2

Rylands French 142: 406-7, 407 n. 43

Maynooth, Russell Library

RB36: 431-32, 432 fig. 1, 433 fig. 2, 436, 438

Mehakelegnaw, Abba Garima Monastery

Gärima I: 363, 363 n. 4, 363 n. 5, 366

n. $10,367-68$

Gärima II: 363 n. 4, 363 n. 5, 366, 366

n. 10,367
Gärima III: 363, 363 n. 4, 363 n. 5, 366, 366 n. 10, 367-68

Naples, Università degli Studi di Napoli

L'Orientale

MS ARA 30: 340 n. 14, 342 n. 21, 343 n.

24, 344 n. 28,347 n. 37, 356

MS ARA 50: 340 n. 14, 340 n. 15, 342 n.

21, 344-45, 344 n. 27, 345 n. 29, 345 n.

30, 345 n. 31, 347 n. 37, 356

MS ARA 51: 356

MS ARA 71: 340 n. 14, 343 n. 24, 347 n.

37, 356

MS ARA 93: 340 n. 15, 343 n. 24, 356

MS ARA 259: 345 n. 30, 345 n. 31, 347

n. 37,356

MS ARA [no shelfmark] "Kitāb al-jawāhir al-muntaqāt”: 345 n. 30, 345 n. 31, 347 n.

37,356

MS ARA [no shelfmark] "Fiqh Ibāḍite": 347 n. 37,356

New York, Metropolitan Museum of Art

57.185.3: 425-26, 427 fig. 2

New York, Morgan Library and Museum MS M.639: 374 n. 33

MS M.828: 363 n. 4, 367, 367 n. 15, 369

n. 28,378 n. 43,381 n. 53

MS M.1078: 396, 397 fig. 9, 409 n. 52

MS M.1112: 425-26, 427 fig. 2

Newark, NJ, Newark Museum

Coll. 96.46.1: 357-58, 358 fig. 1, 365-77, 375 n. 35, 380-82, 380 n. 46-51

Coll. 96.46.2: 357-58, 359 fig. 2, 360, 362, 364 table 1, 365-77, 380-82

Oxford, Bodleian Library

MS Ashmole 792: 306, 312 n. 32

MS. Eng. poet. a. 1: 398, 398 n. 28

MS Junius 11: 396, 396 n. 20

Oxford, Queen's College Library

MS 251: 306, 313, 317-18, 318 n. 40, $320,330,333$ 


\section{Journal For Manuscript Studies}

Paris, Bibliothèque Nationale

MS Éthiopien 32: 365 n. 7, 367-68, 368 n. 18

MS. lat. 964: 435, 435 n. 6

MS. lat. 4892: 435

MS. lat. 5019: 435

MS. lat. 9435: 435

Philadelphia, University of Pennsylvania

MS Codex 85: 442-69, 442 n. 15, 443

n. 16,443 n. 17,443 n. 20,444 n. 21,444

n. 22

MS Codex 736: 441-42, 441 n. 12, 442

n. 14

MS Coll. 390, Item 42: 483

MS Coll. 390, Item 178: 480

MS Coll. 390, Item 292: 484 n. 28

MS Coll. 390, Item 497: 482 n. 25

MS Coll. 390, Item 533: 483, 483 fig. 4

MS Coll. 390, Item 890: 474 n. 10

MS Coll. 390, Item 893: 474 n. 10

MS Coll. 390, Item 896: 474 n. 10

MS Coll. 390, Item 1136: 479 n. 18

MS Coll. 390, Item 1334: 479 n. 19

MS Coll. 390, Item 1567: 482

MS Coll. 390, Item 1783: 485

MS Coll. 390, Item 2053: 484 n. 28

MS Coll. 390, Item 2172: 480

MS Coll. 390, Item 2615: 480, 481 fig. 3

MS Coll. 390, Item 2660: 480

MS Coll. 390, Item 2670: 475 n. 13

MS Coll. 390, Item 2671: 475 n. 13

MS Coll. 390, Item 2672: 475 n. 13

MS Coll. 390, Item 2673: 475 n. 13

MS Coll. 390, Item 2674: 475 n. 13

MS Coll. 390, Item 2675: 475 n. 13

MS Coll. 390, Item 3020: 474

MS Coll. 390, Item 3045: 483

MS Indic 2: 476 n. 15
MS Indic 6: 476 n. 15

MS Indic 10: 274 fig. 1

MS Indic 26: 475 n. 13

MS Indic 28: 275 n. 15

Rossano, Rossano Cathedral, Diocesan

Museum

GA 042: 374 n. 33,422

Šemazānā, Akkala Guzāy, Däbrä Libanos

Monastery

Gospel of Däbrä Libanos: 365 n. 6

Təgray, Church of Qärsäbär Mika’el

Gospels of Qärsäbär Mika'el: 371 n. 32

Vatican City, Biblioteca Apostolica Vaticana

Pal. Gr. 220: 374 n. 33

Vat. Gr. 364: 374 n. 33

Venice, San Lazzaro, Mekhitarist Library

MS 1400/108: 374 n. 33

Vienna, Österreichische Nationalbibliothek Cod. Suppl. Gr. 52: 374 n. 33

Washington, D.C., U.S. Library of

Congress

MS 1-85-154.77: 276 n. 16

Yerevan, Matenadaran

MS 238: 422 n. 4

MS 974: 423, 424 fig. 1, 425

MS 2877: 422 n.4

MS 2930: 422 n. 4

MS 3784: 423 n.6

MS 4813: 423 n.6, 426, 428 fig. 3, 429

MS 4818: 422 n. 4

MS 7456: 422 n. 4

MS 7736: 422 n. 4

MS 9423: 422 n.4

MS 10780: 422 n.4 